ENTREPRENEURSHIP AND SUSTAINABILITY ISSUES

ISSN 2345-0282 (online) http://jssidoi.org/jesi/

2020 Volume 7 Number 4 (June)

http://doi.org/10.9770/jesi.2020.7.4(39)

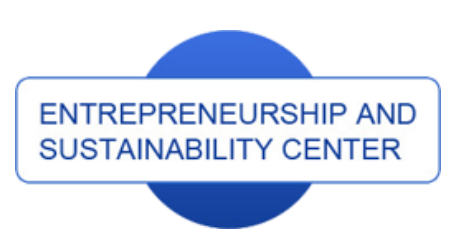

Publisher

http://jssidoi.org/esc/home

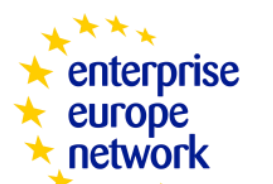

Business Support on Your Doorstep

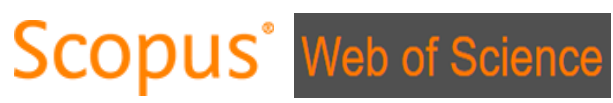

1) Clarivate

\title{
DIGITALIZATION PECULIARITIES OF ORGANIZATIONS: A CASE STUDY*
}

\section{Vladimir Lvovich Vasilev ${ }^{1}$, Almaz Rafisovich Gapsalamov ${ }^{2}$, Elvir Munirovich Akhmetshin ${ }^{3 *}$ Tatyana Nikolaevna Bochkareva ${ }^{4}$, Alexei Valerievich Yumashev ${ }^{5}$, Tatyana Ivanovna Anisimova ${ }^{6}$}

\author{
1,2,3,4,6 Kazan Federal University, Elabuga Institute of KFU, Kazanskaya Street, 89, 423604, Elabuga, Russia \\ ${ }^{5}$ I.M. Sechenov First Moscow State Medical University, Trubetskaya st., 8-2, 119991, Moscow, Russia \\ E-mail: ${ }^{3 *}$ elvir@mail.ru (Correspondingauthor)
}

Received 16 December 2020; accepted 24 April 2020; published 30 June 2020

\begin{abstract}
The relevance of this study is caused by the growing role of digital technology in the organization and functioning of socioeconomic relations. Universities and enterprises are actively using digital technology to realize their traditional functions. Digital transformation requires the adoption of an adequate government policy for the effective management of modern digital processes. The objective is to conduct a study of the digital transformation of universities and enterprises at the micro and macro levels of the socioeconomic system and to formulate some recommendations on improving the efficiency and safety of using digital technologies. As special methods, the authors used the methods of sociological survey and statistical information processing. An institutional approach was used to analyze digitalization processes in the national socio-economic system. The most favorable institutions for the development of digital technologies were identified. A multilevel approach to the analysis of digitalization processes at the personal, organizational and institutional levels was also used. The study revealed a discrepancy in the level of development of the necessary digital competencies between universities and the real sector of the economy. The reason for this was the absence or insufficient development of relevant institutions: trust, competition, entrepreneurship, property rights. Some recommendations were formulated to improve the institutions that promote digitalization, depending on the level of socio-economic activity: personal, organizational, routine.
\end{abstract}

Reference to this paper should be made as follows: Vasilev, V. L., Gapsalamov, A. R., Akhmetshin, E. M., Bochkareva, T. N., Yumashev, A. V., Anisimova, T. I. 2020. Digitalization peculiarities of organizations: a case study. Entrepreneurship and Sustainability Issues, 7(4), 3173-3190. https://doi.org/10.9770/jesi.2020.7.4(39)

JEL Classifications: A13, L70, M14.

\footnotetext{
*The reported study was funded by RFBR, project number 19-29-07037
} 


\section{Introduction}

Currently, digitalization issues are becoming relevant. Digitalization of social and economic relations touched all spheres of human life: household, market transactions, financial activities, banking, industry, agriculture, medicine, education, and government. Together with the positive effects, such as saving time on data transfer and saving the cost of performing work operations (Yli-Viitala et al., 2019), digitalization is also characterized by negative effects - new types of digital fraud and excessive enthusiasm for virtual reality (Tvaronavičienė, 2018; Zhao et al., 2019; Chehabeddine, Tvaronavičienè, 2020). However, scientific and technological progress and limited economic resources necessitate the use of digital technologies throughout the national economy. There is an urgent need to study digitalization processes to reduce negative and increase positive effects. It is necessary to develop a system of institutions that would make digitalization manageable to meet the national development goals and ensure the safety of people's lives. According to these documents, their results should be: an increase in domestic costs for the development of the digital economy from $1.7 \%$ to $5.1 \%$ of the gross domestic product of the country; creation of a stable and secure information and communication infrastructure for the efficient transfer, processing, and storage of large amounts of data between organizations and households; the use of predominant domestic software by state authorities, local governments, private legal entities, and individuals (Vu, 2019; Vural, 2019; Fedulova et al., 2019; Sturm and Quaynor, 2020; Herningsih et al., 2019). The implementation of such large-scale tasks will require the training of appropriate human resources, developers and users of digital technologies. In such circumstances, universities must become digital, and the national innovation system and relevant development institutions must take into account the effects of digitalization (Selomo \& Govender, 2016: Soleimani \& Esfahani, 2018).

The European Commission, as part of the Digital Education Action Plan, has proposed the following definition of digital competence. Digital competence is the willingness and ability of a person to confidently, efficiently, critically and safely apply information and communication technologies in various spheres of life (Dvir \& Yemini, 2017; Amirova et al., 2019; Ivanova et al., 2019; Pavlyshyn et al., 2019). The following components of digital competence are distinguished: knowledge; skills and abilities; motivation; responsibility, including safety. In turn, the digital skills that underlie digital competencies are divided into the following types: user basic digital skills require functional literacy in the use of electronic devices and applications; derivative digital skills consist of the ability to consciously apply digital technologies in everyday life, creative skills for working in digital services are important here; specialized professional digital skills are the basis of high-tech professions, for their development, it is necessary to obtain a special education (Zeibote et al., 2019; Yemelyanov et al., 2018; Masood et al., 2019).

The fact is that a high level of digitalization of the socio-economic system will be achieved only if the digital competence of the population is enhanced. On the other hand, to increase the digital literacy of citizens of the country, it is necessary to create appropriate programs and organizations responsible for this task. That is why it is important to study the institutional conditions for digitalization at both the micro and macro levels. The result of the study is presented in this paper.

\section{Literature review}

By institutions in this study, the authors will mean "rules of the game" or human-created restrictive frameworks that organize relationships between people. In other words, institutions define the structure of the incentive motives of human interaction (North, 1997). External factors, such as scientific and technological progress that brought globalization and digital technology to the world, have an impact on existing institutions, forcing them to change, providing a new framework for human interaction. However, there are reverse processes - the institutions themselves, in particular, the institutions of the national innovation system, have a significant impact on the quality and content of innovation processes and the use of digital technologies to ensure their effectiveness and safety (Freeman, 1987; Lundvall, 1992; Nelson, 1993; Sycheva et al., 2019; Nagimzhanova et al., 2019). In this 
ENTREPRENEURSHIP AND SUSTAINABILITY ISSUES

ISSN 2345-0282 (online) http://jssidoi.org/jesi/

2020 Volume 7 Number 4 (June)

http://doi.org/10.9770/jesi.2020.7.4(39)

regard, there is an urgent task of forming a system of institutions for the development of digitalization of the national socio-economic system at the micro and macro levels.

The modern economy is characterized by the increasing role of knowledge and human capital in the organization of modern industries and services. Science and technology allowed expanding the limited possibilities of economic resources, offered consumers radically new types of goods and services and ensured the growth of national corporations that are actively innovating at the global level (Singareddy et al., 2019; Akhmadeev et al., 2018). There are a number of factors that contribute to these trends. First of all, it is globalization and digitalization of economic relations. Digitalization allows making the interrelation of the sphere of science, education, production and the market closer (almost uniform), and globalization erases the boundaries of national economies. This leads to the fact that modern universities are developing not only their physical infrastructure but also virtual space. This allows universities to form a new intellectual resource in a digital form. Due to the increase in distance education, the time for a deeper study of theoretical and applied course materials increases. At the disposal of teachers in a single digital space of the entire scientific, educational and entrepreneurial sphere, there are hypertext information systems and technologies that improve the quality of education of a future specialist. The task of the state is to promote the digital transformation of universities, shifting the focus from internal, socio-economic problems to market, external conditions of the demand for educational, research products in the real sector of the economy (Nedelkin, 2018; Saenko et al., 2020; Polyakova et al., 2019; Magsumov, 2019a,b; Mullins, 2019; Franco and Bedin, 2019).

The role of universities in shaping the institutions of society has always been a core one (Bykanova and Akhmadeev, 2019). University is a center of knowledge, culture, education, mobilization of individual initiatives, socialization of a person, a construct of social relations. Accordingly, in the context of the orientation of the whole world toward innovation, universities have become a kind of banks of innovative requests and offers, or in other words - innovative hubs. However, for the qualitative fulfillment of this role, the rate of change at universities must be higher than the rate of change in the external environment. The new industrial (digital) revolution 4.0 is a challenge, first of all, for universities. A shift in thinking is needed in order to lead the process of digitalization of the economy (Chichenev, 2019; Sousa et al., 2019; Girdzijauskaite et al., 2019).

Foreign experience in the digital transformation of the economy shows various models of this process. In the literature, a certain classification of the directions of development of a digital economy is given: the production sector (Germany), the service sector (United Kingdom), with priority state support (China), and with priority in the development of private initiatives (USA) (Polozhikhina, 2019). However, the institutional aspects of ensuring efficient and safe digitalization of the economy are not sufficiently addressed in the literature, and for the educational system, the requirements are not formulated to the institutional environment that would ensure the preservation and reproduction of human capital in the context of digital transformation.

\section{Methodology}

This paper used general scientific research methods, such as analysis and synthesis, deduction and induction, the relationship of historical and logical processes, the laws of dialectics, the search for cause and effect relationships. As special methods for research at the micro level, the methods of sociological survey and statistical processing of information were used, and at the macro level, the authors applied the institutional approach for the analysis of digitalization in the national socio-economic system.

Let us describe in more detail the research methodology at the micro level. On the basis of the Elabuga Institute of the Kazan Federal University, a sociological study was conducted on the problems and results of using digital technologies. As a result of the study, the main difficulties in the field of digital competence and the sources of its improvement were identified. The study involved 2,105 students aged $18-23$ years ( $45 \%$ boys and $55 \%$ girls), 
2,103 parents of students and 225 university teachers (43\% male and 57\% female) living in the Republic of Tatarstan, Republic of Udmurtia, Republic of Bashkortostan, Ulyanovsk Region, Samara Region, Orenburg Region and in other territories of the Russian Federation. The purpose of this study was to identify the level, problems, and prospects of the formation of digital competencies in higher education organizations in Russia.

The questionnaire was conducted within one month after the training, using Google forms. To systematize and analyze the results of the survey, an automatically created Google spreadsheet was used. To conduct the survey and analyze its results, written permission was obtained from the respondents for the use of their personal data. There were no refusals to take part in the survey. The questionnaire included 10 questions related to understanding the essence of modern digital competencies (see Table 1).

Table 1. Questions for the analysis of the institutional environment for the formation of digital competencies at the micro level

\begin{tabular}{|c|c|}
\hline Question & Answer options \\
\hline Personal data (age, gender) & $\begin{array}{l}\text { Age: } \\
\text { Gender: }\end{array}$ \\
\hline \multicolumn{2}{|l|}{ Organization in which you work/study } \\
\hline $\begin{array}{l}\text { 1. Are you satisfied with the level of digital technology in } \\
\text { your organization? }\end{array}$ & $\begin{array}{l}\text { yes } \\
\text { no }\end{array}$ \\
\hline $\begin{array}{l}\text { 2. Do you use social networks in your professional } \\
\text { activity? }\end{array}$ & $\begin{array}{l}\text { yes } \\
\text { no }\end{array}$ \\
\hline 3. Evaluate your digital proficiency & $\begin{array}{l}\text { high } \\
\text { medium } \\
\text { low } \\
\end{array}$ \\
\hline 4. Evaluate your experience in using digital technologies & $\begin{array}{l}\text { 1. Less than } 5 \text { years } \\
\text { 2. } 5 \text { to } 10 \text { years } \\
\text { 3. Over } 10 \text { years } \\
\text { 4. Other }\end{array}$ \\
\hline 5. Do you enhance your digital competence? & $\begin{array}{l}\text { 1. From time to time } \\
\text { 2. All the time } \\
\text { 3. I do not pay attention, everything turns out by } \\
\text { itself } \\
\text { 4. Never } \\
\text { 5. Other }\end{array}$ \\
\hline $\begin{array}{l}\text { 6. In your opinion, do digital technologies improve the } \\
\text { educational process? }\end{array}$ & $\begin{array}{l}\text { 1. Yes, they do } \\
\text { 2. No, they do not } \\
\text { 3. They rather do } \\
\text { 4. They rather do not } \\
\text { 5. They do only subject to deep preparatory work } \\
\text { and use without prejudice to personal } \\
\text { communication } \\
\text { 6. Other }\end{array}$ \\
\hline 7. What do you mean by digital competencies? & $\begin{array}{l}\text { 1. The willingness and ability of a person to } \\
\text { confidently, efficiently, critically and safely apply } \\
\text { information and communication technologies in } \\
\text { various spheres of life } \\
\text { 2. The ability to work on the Internet, with various } \\
\text { information products and mobile applications } \\
\text { 3. Other }\end{array}$ \\
\hline $\begin{array}{l}\text { 8. Evaluate the quality of digital knowledge gained at } \\
\text { school/university }\end{array}$ & $\begin{array}{l}\text { 1. High quality } \\
\text { 2. I learned more myself than I was taught at } \\
\text { school/university } \\
\text { 3. Low quality } \\
\text { 4. I know more than school/university teachers } \\
\text { 5. Other }\end{array}$ \\
\hline
\end{tabular}


ENTREPRENEURSHIP AND SUSTAINABILITY ISSUES

ISSN 2345-0282 (online) http://jssidoi.org/jesi/

2020 Volume 7 Number 4 (June)

http://doi.org/10.9770/jesi.2020.7.4(39)

\begin{tabular}{|l|l|}
\hline 9. What do you think is the main task of the & $\begin{array}{l}\text { 1. To teach how to work on the Internet and use } \\
\text { school/university in the formation of your digital } \\
\text { competencies? }\end{array}$ \\
$\begin{array}{ll}\text { 2. To teach to maintain a high level of information } \\
\text { security }\end{array}$ \\
$\begin{array}{ll}\text { 3. To transfer the main educational process to } \\
\text { distance technologies } \\
\text { 4. To provide ongoing training in digital } \\
\text { technologies }\end{array}$ \\
$\begin{array}{ll}\text { 5. Other } \\
\text { life will be expanded or reduced? }\end{array}$ \\
$\begin{array}{l}\text { 1. It will strengthen only in professional activities } \\
\text { 2. It will strengthen everywhere: at work, at home, } \\
\text { on vacation }\end{array}$ \\
$\begin{array}{l}\text { 3. It will decrease } \\
\text { 4. Other }\end{array}$ \\
\hline
\end{tabular}

Based on the analysis of questionnaires, an assessment was made of the effectiveness of the existing institutional environment in the formation of digital competencies in the education system in Russia.

The authors will describe in more detail the methodology for studying the institutional environment for the development of digitalization processes at the macro level. The method of SWOT analysis and a multi-level approach to the study of digitalization processes at the personal, organizational and institutional levels were used. SWOT analysis is a strategic planning method consisting in identifying factors of the internal and external environment of educational organizations and dividing them into four categories: Strengths, Weaknesses, Opportunities, Threats. Strengths and weaknesses are factors in the internal environment of the Russian education system; opportunities and threats are factors in the external environment of the Russian education system. The objective of SWOT analysis is to provide a structured description of the existing institutional environment for the development of digitalization processes in the Russian education system and in the national economy as a whole. At the same time, the study decided to formulate recommendations on improving the institutional environment for using digital technologies at the individual person level - the personal level, at the enterprise and university level - the organizational level, at the level of existing norms and laws - the routine level. This approach was justified by the fact that the processes of exchange of information and knowledge at different levels require different institutional conditions. The results of such a study at the macro level are presented in this paper.

\section{Results}

\section{Research of the institutional environment of digital transformation processes at the micro level}

As already noted, human resources are a prerequisite for the successful digitalization of the economy. A modern employee must have a set of digital competencies. Here are briefly described results of the studies (Figures 1, 2, $3)$. 
ENTREPRENEURSHIP AND SUSTAINABILITY ISSUES

ISSN 2345-0282 (online) http://jssidoi.org/jesi/

2020 Volume 7 Number 4 (June)

http://doi.org/10.9770/jesi.2020.7.4(39)

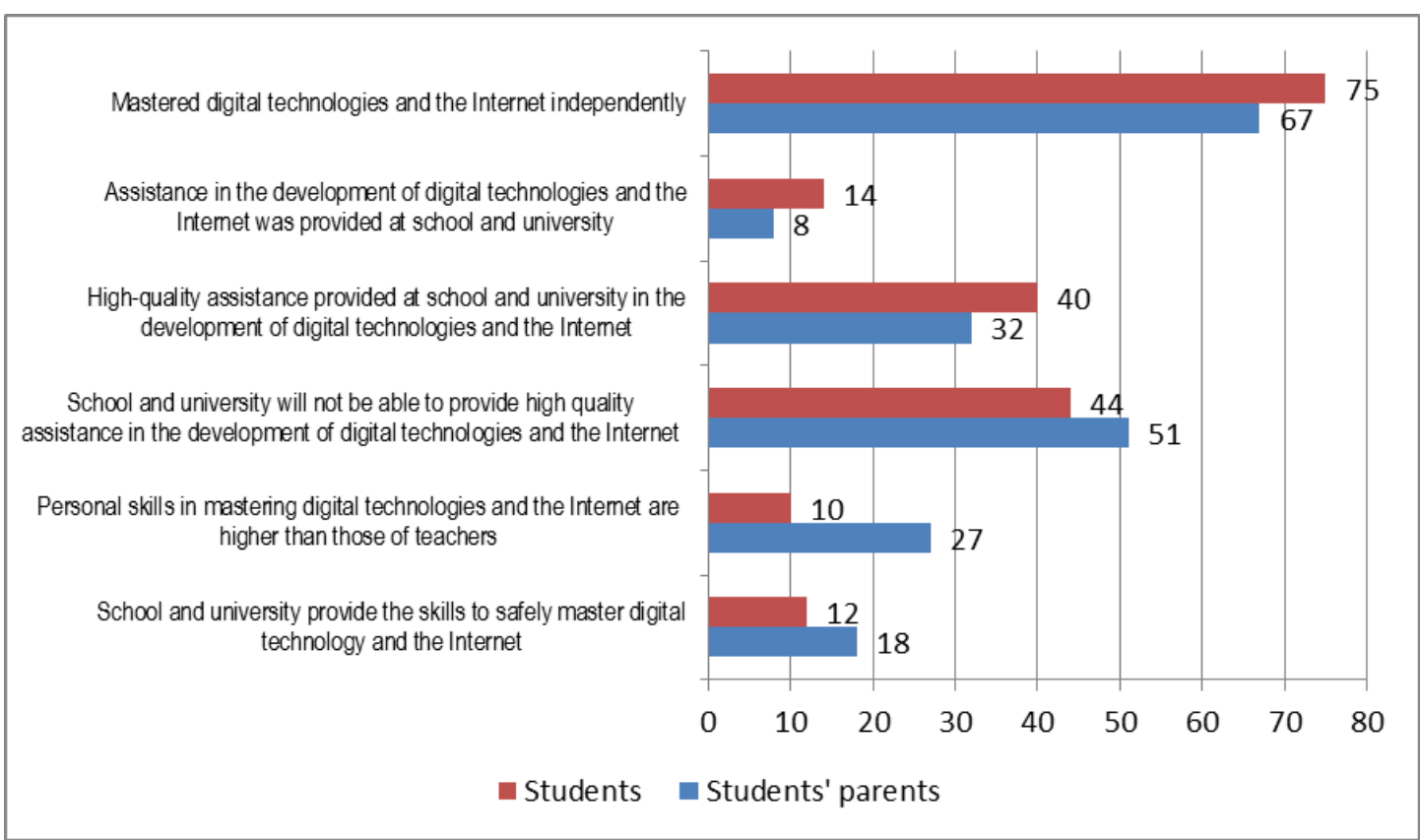

Figure 1. Answers to the question "How did you gain knowledge and skills in using digital technologies and the Internet?" Source: Prepared by the researchers

Now let us describe the indicators presented in Figure 1:

1. Sixty-seven percent of adults and $75 \%$ of students studied using the Internet on their own.

2. Only $14 \%$ of students indicated that they were taught to use the Internet at school.

3. Students rated the help of school teachers weakly: only $40 \%$ of students are fully or partially satisfied with the knowledge about the use of the Internet received at school.

4. At the same time, $44 \%$ of students believe that the school does not give them any useful knowledge in this area or is generally unable to teach them.

5. One out of ten students claims to know more than teachers about the Internet.

6. Only every tenth student received information on the safe use of the Internet at school.

Teenagers and their parents differently assess the role of school and university in the formation of digital competencies. Most students have more positive opinions about the school and the university on the acquired knowledge and skills. Students' parents have fewer positive opinions in this regard. This is explained by the fact that the format of the school and university has changed significantly recently due to changes in the institutional environment focused on digital transformation (Digital Educational Environment: New Teacher Competencies, 2019). On the other hand, students have less positive expectations from school and university than their parents. This is because students see the situation more deeply, as they are more familiar with the risks and threats of modern digital technologies. Now, the authors are presenting the results of the respondents' assessment of the sources of digital competence. 


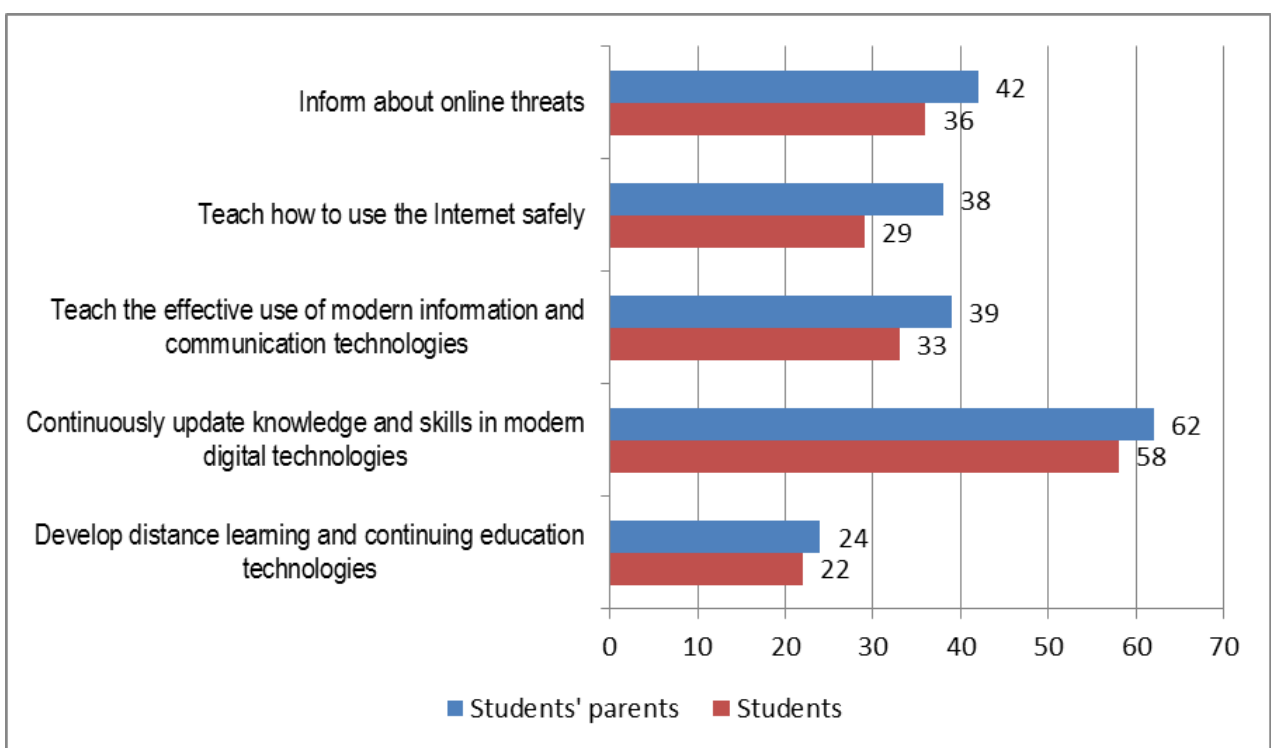

Figure 2. Answers to the question "In your opinion, what knowledge and skills should be taught at school and university?" Source: Prepared by the researchers

The indicators presented in Figure 2 show the following:

1. Inform about online threats (42\% of parents and $36 \%$ of students);

2. Teach how to use the Internet safely ( $38 \%$ of parents and $29 \%$ of students);

3. Teach the effective use of modern information and communication technologies (39\% of parents and $33 \%$ of students);

4. Continuously update knowledge and skills in modern digital technologies $(62 \%$ of parents and $58 \%$ of students);

5. Develop distance learning and continuing education technologies (24\% of parents and $22 \%$ of students).

It can be noted that neither among parents nor, to a greater extent, among students, the university still enjoys any authority in the field of mastering the capabilities of digital technologies. The difference in the results of the answers of parents and students is caused by the changed institutional conditions of the past and modern education and economy systems (Soldatova et al., 2013). The backlog of university education from economic trends is becoming more noticeable in the face of accelerating rates of scientific and technological progress.

Considering the results of a study of the accumulated digital competencies of university teachers, in this survey, the majority of respondents are teachers aged 36 to $55(63 \%)$, women $-88 \%$. More than half of the teachers (52\%) taught humanitarian and public subjects, the second smaller part (48\%) taught STEM subjects. Work experience was over 20 years for $56 \%$ of teachers, from 11 to 20 years for $23 \%$ of teachers, less than 10 years for $21 \%$. 


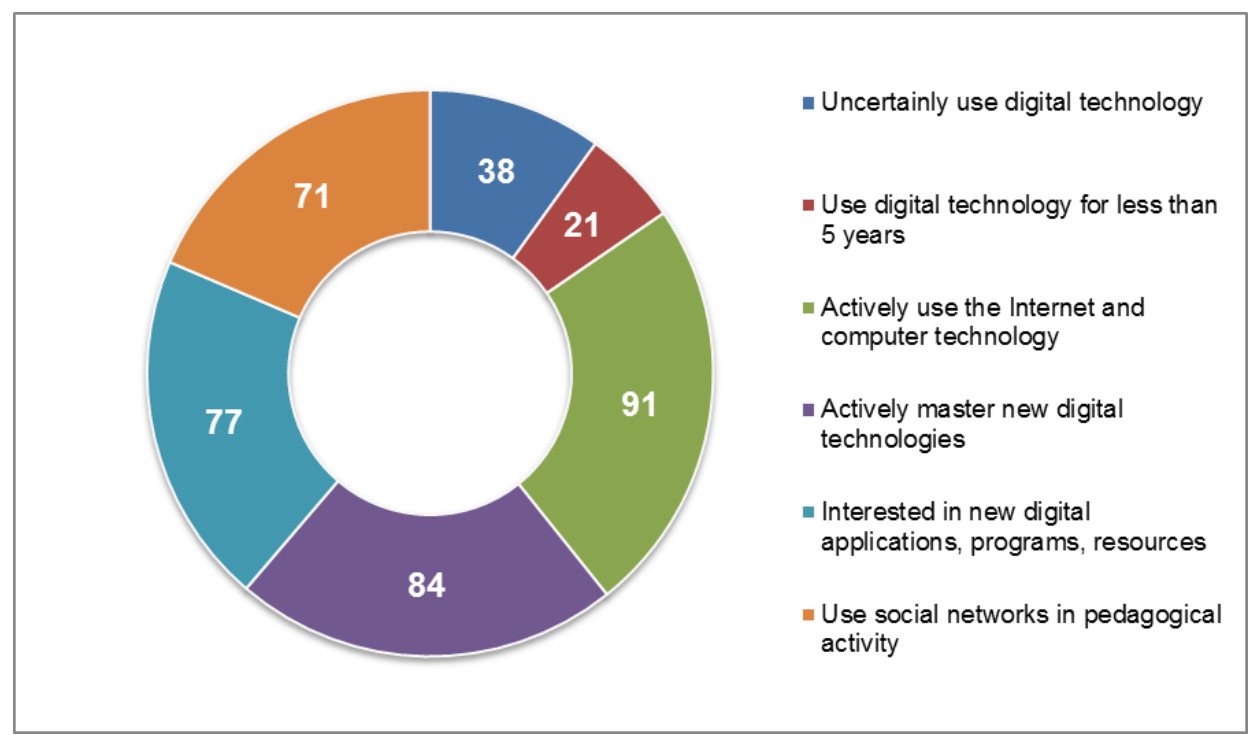

Figure 3. Evaluate the quality of accumulated digital competencies

Source: Prepared by the researchers

The indicators presented in Figure 3 show the following:

1. According to estimates of $38 \%$ of teachers, from 40 to $100 \%$ of their colleagues use digital technologies uncertainly or do not use them at all.

2. One fifth $(21 \%)$ of teachers have been using digital technology for less than 5 years.

3. The majority of teachers (91\%) actively use the Internet and do not experience difficulties with working on a computer and other digital devices (84\%). At the same time, teachers are interested in new applications, software, and resources $(77 \%)$ and actively use social networks $(71 \%)$.

Therefore, teachers believe that most of them use digital resources very efficiently, however, students and their parents talk about the lack of digital knowledge and skills acquired at the university. Accordingly, a discrepancy in the assessments of the accumulated and acquired level of digital competencies at the personal level between teachers, students, and their parents is revealed. At the organizational level, this mismatch of assessments occurs between universities and the real sector of the economy (Aimaletdinov et al., 2019). For this reason, it is necessary to form educational programs for the formation of digital competence in students, in demand under modern conditions of economic and social development. A high level of general motivation to increase digital competence both for parents and students (more than 60\%) with a low level of digital competence (one-third of the maximum possible) indicates the demand for the development of educational programs in this area.

\section{Research of the institutional environment of digital transformation processes at the macro level}

Modern conditions for the development of the economy dictate the need for cooperation between industrial companies and universities. Modern corporations conduct research with a fifty-year planning horizon. Leadership in digital technology is currently provided by fundamental science. Research covers the entire life cycle of a digital product. Attention is paid to all stages of the innovation chain to ensure self-sufficiency. The main threats to digitalization for the corporate sector are to lag behind competitors. Accelerating the pace of scientific and technological development leads to the need to work ahead of competitors. Technological depreciation comes faster than physical depreciation. The contribution of intellectual labor in such conditions is constantly increasing. The research departments of modern corporations, for example, Huawei, are already approaching half of the headcount. Currently, with a total number of 180 thousand people in 170 countries, Huawei has 14 laboratories with 80 thousand researchers, 8 thousand of which are in the Russian Federation (Guo, 2019). From the point of view of the protectionist approach to education, the modern policy of private market companies, especially 
transnational ones, has a devastating effect. In other words, modern multinational companies operate as global "vacuum cleaners" of unique human capital in their own interests. Digital technology allows one to do this without leaving a place of residence. Thus, a commercially attractive corporate intellectual resource is created. There is a conflict of interests with the sources of the formation of human capital, primarily with the education system of the national economy. In the priorities of national policy, mechanisms must be created to ensure reverse financial flows from transnational corporations to the education system, where the demanded human capital is mainly formed.

Modern leaders in the production and use of digital technologies, for example, Microsoft, also participate in the formation of new digital technologies, adapting them to the corporate university network (Graham et al., 2019; Jarrah, 2019). Currently, students have the opportunity to choose: study in the university building or watch a video broadcast of lectures on the Internet. The technology of social computer networks can be extended to the educational process. The moderator of the topic is the teacher, he/she coordinates the discussion, gives tasks, students complete them, communicate with each other and the teacher, complement each other's answers, and critically look at the educational process. Thus, a common intellectual resource is created. In addition, for solving comprehensive problems, modeling and assessing a problem situation, teachers and students have the opportunity to use new digital technologies - artificial intelligence, big data analysis, blockchain, and the Internet of things. The study at the macro level made it possible to compile a matrix of SWOT analysis and outline the appropriate directions for improving the institutional environment for the development of digitalization of the national socioeconomic system (Table 2).

Table 2. Results of a SWOT analysis of the digital transformation of education and the economy

\begin{tabular}{|c|c|}
\hline Strengths & Weaknesses \\
\hline $\begin{array}{l}\text { 1. The high level of academic, fundamental, theoretical training } \\
\text { of applicants, students, and graduate students due to the legacy } \\
\text { of the Soviet educational system } \\
\text { 2. The availability of natural resources, territory, infrastructure, } \\
\text { power capacities, budgetary resources to fulfill the indicators to } \\
\text { increase the digital literacy of the population } \\
\text { 3. A sufficiently high level of teaching staff (the Kazan Federal } \\
\text { University ranks } 94^{\text {th }} \text { in the TOP } 100 \text { universities of the world by } \\
\text { "Education" in the Times Higher Education rating) } \\
\text { 4. High level of informatization and computerization of the } \\
\text { Russian economy ( } 28^{\text {th }} \text { place in the world) }\end{array}$ & $\begin{array}{l}\text { 1. Lack of a systematic policy in teaching the supersubject } \\
\text { competencies in demand in a digital economy (the ability to learn, } \\
\text { master new knowledge and technologies, incentive and entrepreneurial } \\
\text { spirit) } \\
\text { 2. Lack of effective and long-term mechanisms for reverse financial } \\
\text { flows from transnational corporations to the national educational } \\
\text { system } \\
\text { 3. Inadequate interaction between universities and enterprises, } \\
\text { including the level of use of digital technologies and the formation of } \\
\text { digital competencies } \\
\text { 4. Commission costs for the implementation of digitalization (low level } \\
\text { of domestic software and hardware of digital infrastructure) } \\
5 \text {. Lack of effective regulatory tools in international and national } \\
\text { copyright laws }\end{array}$ \\
\hline Opportunities & Threats \\
\hline $\begin{array}{l}\text { 1. A transition to a new scientific and technological lifestyle } \\
\text { based on digital technology } \\
\text { 2. Formation of a protectionist model of digital education } \\
\text { 3. Capturing new markets (willing to work and study remotely) } \\
\text { 4. Stimulating the development of new jobs } \\
\text { 5. Stimulating export growth of knowledge } \\
\text { 6. Changing the structure of the economy and education, } \\
\text { increasing the productivity of these sectors }\end{array}$ & $\begin{array}{l}\text { 1. Loss of leadership in digital technology due to a significant } \\
\text { dependence on foreign developments of the previous scientific and } \\
\text { technical wave } \\
\text { 2. The flow of the highest quality human resources abroad (remote } \\
\text { work for multinational companies without a change of residence or } \\
\text { employment in local branches of these companies) } \\
\text { 3. Loss of control over digital infrastructure } \\
\text { 4. Loss of control over knowledge distribution channels } \\
\text { 5. The emergence of new competitors } \\
\text { 6. Lack of effective tools to control the owners of digital content and } \\
\text { Internet sites }\end{array}$ \\
\hline
\end{tabular}


To assess the degree of digitalization of the economy for all countries, the Digital Evolution Index is calculated, according to which Russia in 2017 ranked 39th out of the 60 countries studied, while in 2013 Russia was 40th. This rating includes indicators in key areas, such as the supply and demand for digital technology, the institutional environment, and the innovation climate. As a result of the study by the parameters of digital transformation, the countries were divided into four groups: the leaders - distinguished (Singapore, Great Britain, New Zealand, the United Arab Emirates, Estonia, Hong Kong, Japan, Israel), the slowing growth rates - silent (South Korea, Australia, countries of Western Europe and Scandinavia), promising - breaking through (China, Kenya, Russia, India, Malaysia, Philippines, Indonesia, Brazil, Colombia, Chile, Mexico), problematic - out of concern (South Africa, Peru, Egypt, Pakistan, Greece) (The top 10 digital-competitive countries, 2017). The study identified a modern factor of success in digitalizing a country's economy, the level of confidence, which is gaining importance. The level of confidence, in turn, depends on such indicators as consumer behavior and attitude toward new technologies, the experience of their use and innovative climate. Thus, all the traditional problems of the Russian economy, which in recent years have hindered its innovative breakthrough, also serve as an obstacle to the digital transformation of society. Until the necessary level of confidence is accumulated in the business environment, in the civil society, in the education system, in the relation of people to the government and the state policy of supporting innovation - a radical leap to a new digital economy will not happen. The level of confidence also depends on the moral standards of behavior in society, the degree of criminalization, and the risks of nonfulfillment of market contracts. In other words, innovators will not develop new digital technologies and services unless they trust the institution for the protection of intellectual property rights. Entrepreneurs will not actively sell developed digital technologies and services if they do not trust the institution of fair competitive relations. Consumers will not begin to use digital technologies and services if they do not trust the institution of contract market relations. Accordingly, one can formulate the components of the institutional mechanism for the development of the digitalization of the national socio-economic system (Figure 4).

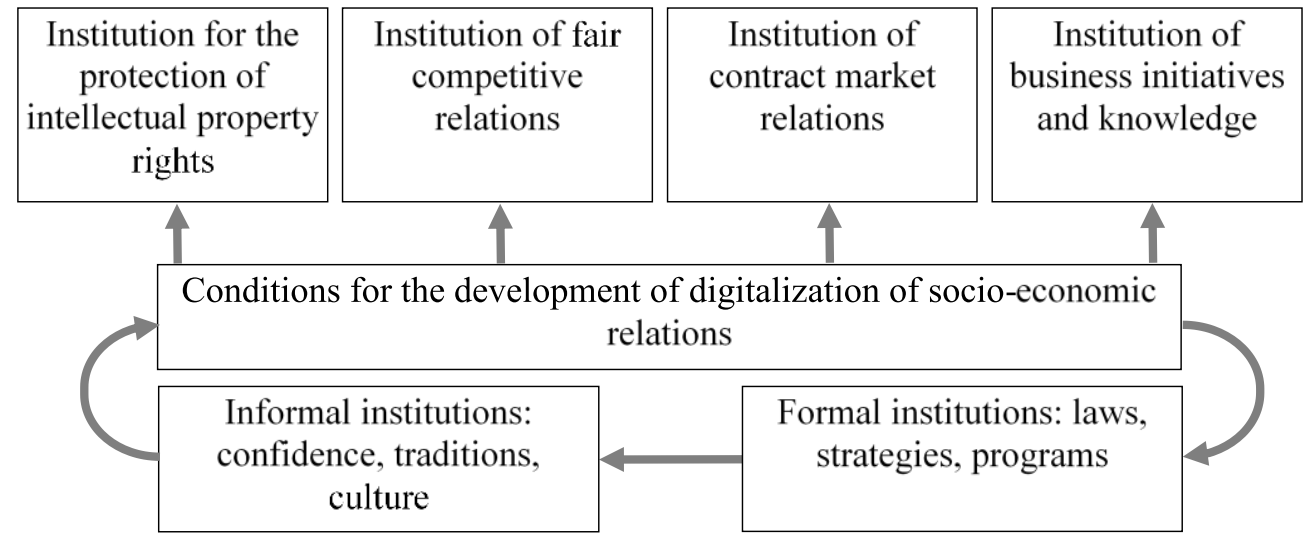

Figure 4. The institutional mechanism for the development of digitalization of the national socio-economic system Source: Prepared by the researchers

To accelerate the digital transformation of the education system, institutions to stimulate the use of digital technologies are required. Stimulation should be indirect in nature and ensured by integrating digital media into the learning process. Adequate digital infrastructure is needed. This will motivate the active use of digital technology. Another important step is to ensure digital literacy, not only in the professional field, but also in interdisciplinary, and even in everyday activities. It is necessary to develop an institution of consistent, lifelong, from the early years, training in digital literacy and the formation of digital competencies. Employers already require such competencies from future university graduates. It is also necessary to improve the institution of intellectual property and copyright in the use of digital technologies. Knowledge and information, which are the main objects of use in digital technologies, have the property of being inseparable from their source and, accordingly, need more complex protection of commercial rights to use them. On the other hand, knowledge and 
ENTREPRENEURSHIP AND SUSTAINABILITY ISSUES

ISSN 2345-0282 (online) http://jssidoi.org/jesi/

2020 Volume 7 Number 4 (June)

http://doi.org/10.9770/jesi.2020.7.4(39)

information also have the property of "club goods", the value of which only increases with increasing use. Such contradictions impose requirements for the improvement of copyright law.

\section{Discussion}

Researchers of the digitalization phenomenon note significant changes in all areas of socio-economic activity, including in higher education (Vasetskaya, 2018; Ziyadin et al., 2018; Tikhonov et al., 2019). Digital transformation has the following impact on universities:

1. The introduction of basic information services - the creation of a single digital space. This direction allows all participants in the educational and research process to interact in digital format. Students have the opportunity to build their individual educational trajectory, do any distance online courses, regardless of the place and time of their stay (Korableva et al., 2019a, b).

2. Creation and implementation of the University 4.0 service, including research project management, procurement management, scientometrics digitalization, interaction with teachers and students. This direction allows building on a new basis the processes of interaction of all participants in research activities. Digitalization helps organize knowledge-sharing communications more efficiently. The interaction takes place in real time. Teachers, employees of scientific departments and students can jointly solve the tasks of innovation.

3. The orientation of the university to the implementation of "smart manufacturing". In this direction, the university becomes a member of the new digital space related to the introduction of Internet technologies in economic activity, production and services, household activities and everyday human life. Such technologies as cognitive procedures, on-line things management, big data analysis, and cloud storage have become widespread.

It seems relevant to study a digital transformation of the university as a process of creating new business conditions, the interaction of all students and university staff on a new, digital platform integrated into the digital economy platform of the country and the world. Digital technology allows creating a digital profile of a student, taking into account his/her individual, physical, psychological, national and social characteristics. This allows choosing the most appropriate digital profile tools and training methods (online and offline, problematic, practiceoriented), as well as the mode and forms of training (full-time and distance, mixed, individual and group). Thus, the student's digital profile is another element in shaping the digital system of the new university (Bockshecker et al., 2018: Villalobos, 2018).

The modern digital environment of the university is a combination of information systems, technologies, and services that allow conducting educational, research, methodological, administrative and business activities in digital format, working remotely, in real time via the Internet from anywhere in the world to enter information into the digital environment of the university and use the data presented in it. The digital environment of a modern university has such properties as security, openness, accessibility, flexibility, reliability, responsiveness, and informational content. The digital system of a modern university consists of an Internet portal, personal accounts of students, personal accounts of teachers and staff, electronic educational resources, libraries and reference books, modules for the automation of educational, administrative and financial activities. The digital capabilities of a modern university make it possible to automate the traditional workflow (Rosa et al., 2019), the formation of contracts, orders, resolutions, reports, service requests and other management decisions. The introduction of data analysis units into the digital environment of a modern university will provide opportunities for assessing the individual characteristics of students and teachers, the formation of individual educational trajectories and joint scientific research. The integration of the digital environments of universities in the future may lead to the emergence of a universal, mixed, human-machine intellectual resource, which allows bringing the development of innovative activity to a new level.

From the point of view of philosophical and methodological analysis, University 4.0 is an element of a cognitive society, where the processes associated with the production, processing, exchange and distribution of information 
ENTREPRENEURSHIP AND SUSTAINABILITY ISSUES

ISSN 2345-0282 (online) http://jssidoi.org/jesi/

2020 Volume 7 Number 4 (June)

http://doi.org/10.9770/jesi.2020.7.4(39)

become core ones. The producer of knowledge is becoming the collective and hybrid (human-machine) intelligence. Digital technologies allow the use of human and machine intelligence to solve complex problems not only in production but also in the cultural and social spheres. The society acquires the nature of network interaction, and an individual gets the opportunity to use the collective mind. An individual can influence the activities of other people in real time using digital technology and the Internet. In these conditions, a special culture of will and trust is needed, which ensures the concentration of cognitive capabilities, fixation of meanings and intentions, critical filtering of information and communications. Universities are turning into a platform of collective knowledge, while any facets with the external environment are erased. University employees and students actively participate in joint search activities to form common meanings, while at the same time maintaining their individual attitudes and building effective communicative connections. The university's functions are shifting towards coordinating promising research, launching startups, deploying and improving a communications network, and promoting digital technologies (Efimov \& Lapteva, 2017).

According to scholars, the modern digital era is characterized by the emergence of such innovations, the creation of which required the cooperation of many people, various professions and motivations. The conditions created at a company or a university for the exchange of knowledge, and in the long run for that at the level of intercorporate (inter-university) cooperation, are a key factor in the success of any innovation process, including the creation and use of digital technologies (Yagolkovsky, 2011). The free exchange of knowledge creates a comfortable socio-psychological climate for employees (Yankovskaya et al., 2019). The factors influencing free information exchange are: confidence, creative motivation, corporate culture, cognitive activity (Brachos et al., 2007). Accordingly, at the personal level and in the first stages of using digital technologies, it is necessary to take such measures that would facilitate the free exchange of knowledge and information. On the other hand, corporations and universities are organizations that operate in a market economy and compete for various economic resources. Corporations are fighting for consumers of their products, universities are seeking for applicants. Digital technology exacerbates this rivalry, making it more dynamic and versatile. The largest sales proceeds go to those companies that have launched the making of competitive products at the most attractive prices and quality. Budget resources are provided to universities that also have more attractive results of research, employment of graduates, contractual business relations with the real sector of the economy. Competition at the organizational level is an incentive for the development of their corporate information systems, digital educational technologies, digital environment and communications. Competition is recognized as an incentive for all innovations (Schumpeter, 1982). Accordingly, the government needs to support the competitive process at the level of corporations and universities, at the organizational level. For this, rating mechanisms and competitions are widely used in Russia and the world, as a result of which financing is provided. The conditions for the development of a competitive environment are: private property, freedom of entrepreneurial activity, freedom of consumer choice, priorities of personal interest, and a limited role of the government (Khasanova, 2016). Thus, at the organizational level and at the stages of using digital technologies, where intellectual property rights are clearly defined, the development of appropriate institutions is necessary: competitive conditions, state support on competitive terms, public centers for collective use.

The protectionist model of Russian education proposed by the authors in the context of the digitalization of the economy should include at the personal level of using digital technologies the institutions of cooperation and knowledge sharing, and at the organizational level and stages of the market interaction of participants in the digital environment, the institutions of competition and fair competition for limited economic resources, including human capital.

In this regard, the state policy to attract and keep the best personnel in the education system should take into account this thesis. The point is not to let personnel go abroad or work for transnational companies, but to create special conditions to stimulate the creative development of scientists, researchers, innovators and to maintain high competitiveness of Russian universities and the real sector of the economy. 
ENTREPRENEURSHIP AND SUSTAINABILITY ISSUES

ISSN 2345-0282 (online) http://jssidoi.org/jesi/

2020 Volume 7 Number 4 (June)

http://doi.org/10.9770/jesi.2020.7.4(39)

\section{Findings and Recommendations}

The study of the institutional environment at the micro level using the example of the university made it possible to formulate the following conclusions and recommendations. Educational programs should include the following elements:

- motivational, aimed at setting specific goals, demonstrating the capabilities and importance of digital learning;

- modeling, the main task is to visualize the model of "a citizen of the digital world".

Among other things, the structure of programs should take into account the peculiarities of the activities of parents and students on the Internet, since the use of digital devices increases significantly on weekends, and students themselves are focused on quickly receiving the necessary information. Therefore, educational programs are required that are not tied to the school working schedule, accessible from anywhere and at any time, and aimed at stimulating the exchange of experience and cooperation.

An effective educational program should pay attention to the development of responsibility and the possibility of ensuring the safety of students and parents in the digital space, as well as the development of specific skills on the Internet, namely: working with information; communication; technological sphere; consumption. In addition, both adults and students need to form an active and independent position on the Internet. When working with parents, the most important task is to bridge the digital gap and teach them the correct assessment of their capabilities to help students work on the Internet.

It should be noted that Russian users are more likely to be involved in a digital competence-building program offering them communication, collaborative search, and developmental games than in a program similar to an electronic textbook. Thus, the importance of the conscious and responsible use of digital technologies in training and everyday activities on the basis of confidence between users of digital products is emphasized. The results of the above studies indicate the presence of many difficulties in the process of forming digital competencies in students in Russia. According to the foreign classification, the digital skills that underlie digital competencies are divided into user and specialized. The authors believe that digital competence must include, in addition to special knowledge, skills and abilities, the ability to digital cooperation, to ensure its security and solve digital problems. A major role in this process is played by: the personality of the teacher, his/her professionalism, desire to develop; educational opportunities; parental activity and mobility; the level of motivation for learning among students themselves.

The study of the institutional environment at the macro level using the example of the national education system and the economy made it possible to formulate the following conclusions and recommendations. The modern education system is at the stage of active digital transformation. Each university is developing its own digital environment. A significant part of the university's traditional activities is carried out in digital format and this part is rapidly increasing. Universities are drifting smoothly toward the University 4.0 model, which is characterized by the total digitalization of all types of activities: educational, methodological, scientific, financial, economic, and entrepreneurial.

The real sector of the economy is in a digital transformation to an even higher degree. Moreover, the gap in digital development and digital competence achieved is gradually widening between universities and the real economy. This is largely due to the most effective institutional incentives created in the market sector: competition, entrepreneurship, property rights. To make a profit, enterprises are forced to become digital. University education, mainly funded by the state, is also becoming digital, under the indirect influence of market incentives. The employment of graduates, as the main criterion of the demand for a university, largely depends on the digital competencies of future specialists obtained at the university. 
ENTREPRENEURSHIP AND SUSTAINABILITY ISSUES

ISSN 2345-0282 (online) http://jssidoi.org/jesi/

2020 Volume 7 Number 4 (June)

http://doi.org/10.9770/jesi.2020.7.4(39)

To improve the digitalization processes of universities and enterprises in the interests of the national socioeconomic system, the development of appropriate institutions is necessary. The key institution is confidence, as the main condition for the effective and safe development of digitalization processes. This study has shown that with a low level of confidence between users of digital technologies, the negative effects of digitalization increase and the positive ones decrease. The time and resource savings achieved through digital technology tend to zero if users begin to increase the cost of security and duplication of electronic information on tangible media.

The state policy for the development of digitalization should take into account the levels of socio-economic activity of users. At the personal level, measures to support cooperation, confidence and information exchange are paramount. At the organizational level, priority is given to measures to support competition, intellectual property rights, contractual relations, entrepreneurial (digital) initiatives and knowledge. The state, using formal institutions (laws, strategies, programs) should ensure the formation of relevant informal institutions (confidence, traditions, culture). This process will be effective if adequate measures for the development of digital relations are formulated and implemented for various levels of the socio-economic system.

\section{Conclusion}

Thus, the study at the micro level of the institutional environment for the digitalization of Russian universities revealed quite important trends. First of all, this is a mismatch of assessments in obtaining digital competencies between universities and the real sector of the economy. Accordingly, this made it possible to clarify the research program for analyzing the institutional environment of digitalization of Russian education at the macro level, in the interests of the national economy. The formulated recommendations on improving the development of digitalization of the socio-economic system will ensure the development and implementation of an effective public policy for all levels of education.

\section{Acknowledgments}

The reported study was funded by RFBR, project number 19-29-07037

\section{References}

Aimaletdinov, T.A., Baimuratova, L.R., Zaitseva, O.A., Imaeva, G.R., Spiridonova, L.V. (2019). Digital literacy of Russian educators. Willingness to use digital technology in the educational process. Moscow: NAFI Publishing House.

Akhmadeev, R.G., Kosov, M.E., Bykanova, O.A. \& Turishcheva, T.B. (2018). Development of venture financing to ensure economic security of a country. Proceedings of the 32nd International Business Information Management Association Conference, IBIMA 2018 Vision 2020: Sustainable Economic Development and Application of Innovation Management from Regional expansion to Global Growth, 51-56.

Amirova, E. F., Voronkova, O. Y., Zakirova, N. R., Stepanenko, O. G., Doguchaeva, S. M., \& Murzagalina, G. M. (2019). Internet of things as a tool for development of russia's digital economy. International Journal of Mechanical Engineering and Technology, 10(2), 10111019

Bockshecker, A., Groer, B., Hackstein, S., Hochberg, J., Schellberg, U., Vogel, C., Bastiaens, T. J. (2018). Academic media architecture for digital learning environments in higher education. Paper presented at the MKWI 2018 - Multikonferenz Wirtschaftsinformatik, 2018March 869-880.

Bykanova, O.A. \& Akhmadeev, R.G. (2019). Universal VAT Loyalty Policy for B2B E-Commerce. Proceedings of the 34th International Business Information Management Association Conference, IBIMA 2019: Education Excellence and Management of Innovations through Sustainable Economic Competitive Advantage, 3046-3051. 
ENTREPRENEURSHIP AND SUSTAINABILITY ISSUES

ISSN 2345-0282 (online) http://jssidoi.org/jesi/

2020 Volume 7 Number 4 (June)

http://doi.org/10.9770/jesi.2020.7.4(39)

Brachos, D., Kostopoulos, K., Soderquist, K. E., Prastacos, G. (2007). Knowledge Effectiveness, Social Context and Innovation. Journal of Knowledge Management, 11(5), 31-44.

Chehabeddine, M., Tvaronavičienè, M. (2020). Securing regional development. Insights into Regional Development, 2(1), 430-442. http://doi.org/10.9770/IRD.2020.2.1(3)

Chichenev, S. (2019). Another reference point. Expert Northwest, 2 (767), 10-13.

Decree of the President of the Russian Federation dated 09.05.2017 No. 203 "On the Strategy for the Development of the Information Society in the Russian Federation for 2017 - 2030" (2017, May 09). The official Internet portal of legal information.

Digital educational environment: new competencies of a teacher (2019). Materials of the II All-Russian Scientific and Practical Conference (2018, December 19-21).

Dvir, Y., \& Yemini, M. (2017). Mobility as a continuum: European commission mobility policies for schools and higher education. Journal of Education Policy, 32(2), 198-210. http://doi.org/10.1080/02680939.2016.1243259

Efimov, V.S., Lapteva, A.V. (2017). University 4.0: philosophical and methodological analysis. University Management: Practice and Analysis, 21(1), 16-29.

Fedulova, I., Ivanova, V., Atyukova, O., \& Nosov, V. (2019). Inclusive education as a basis for sustainable development of society. Journal of Social Studies Education Research, 10(3), 118-135.

Franco, V. D. A., \& Bedin, E. (2019). The chemistry teaching and the high school student: A case study in the state basic education of esteio city, brazil. [O ensino de química e o aluno do ensino médio: Um estudo de caso na educação básica estadual do Município de Esteio, Brasil] Periodico Tche Quimica, 16(33), 118-129.

Freeman, C. (1987). Technology Policy and Economic Performance: Lessons from Japan, London: Frances Pinter.

Girdzijauskaite, E., Radzeviciene, A., Jakubavicius, A. (2019). Impact of international branch campus KPIs on the university competitiveness: FARE method. Insights into Regional Development, 1(2), 171-180. https://doi. org/10.9770/ird.2019.1.2(7)

Graham, S., Min, J., \& Wu, T. (2019). Microsoft recommenders tools to accelerate developing recommender systems. Paper presented at the RecSys 2019 - 13th ACM Conference on Recommender Systems, 542-543. http://doi. org/10.1145/3298689.3346967

Guo, L., Zhang, M. Y., Dodgson, M., \& Gann, D. (2019). Huawei's catch-up in the global telecommunication industry: Innovation capability and transition to leadership. Technology Analysis and Strategic Management, 31(12), 1395-1411. http://doi.org/10.1080/09537325.2019.1615615

Herningsih, Tchuykova, N. M., Shankar, K., Wekke, I. S., \& Qadri, M. N. (2019). The starbucks effect: It affects on nearby organization. Journal of Critical Reviews, 6(5), 160-165. http://doi.org/10.22159/jcr.06.05.28

Ivanova, V., Poltarykhin, A., Szromnik, A., \& Anichkina, O. (2019). Economic policy for country's digitalization: A case study. Entrepreneurship and Sustainability Issues, 7(1), 649-661. http://doi.org/10.9770/jesi.2019.7.1(46)

Jarrah, H. Y. (2019). Six thinking hats: An analysis of the skill level of jordanian vocational education teachers and the extent of skill application. Space and Culture, India, 7(1), 170-185. http://doi.org/10.20896/saci.v7i1.470

Khasanova, A. Sh., Mirzagalyamova, Z. N., Fatykhova, L.I. (2016). Guidelines for the effective development of Russia. Bulletin of Economics, Law and Sociology, 4, 107-112.

Korableva, O., Durand, T., Kalimullina, O., \& Stepanova, I. (2019a). Usability testing of MOOC: Identifying user interface problems. Paper presented at the ICEIS 2019 - Proceedings of the 21st International Conference on Enterprise Information Systems, $2468-475$.

Korableva, O., Durand, T., Kalimullina, O., \& Stepanova, I. (2019b). Studying user satisfaction with the MOOC platform interfaces using the example of coursera and open education platforms. Paper presented at the ACM International Conference Proceeding Series, 26-30. doi: $10.1145 / 3322134.3322139$

Lundvall, B. A. (1992). National Systems of Innovation. Towards a Theory of Innovation and Interactive Learning, London: Pinter Publishers.

Magsumov, T.A. (2019a). Apprenticeship in secondary vocational schools during the economic modernization in late imperial Russia. Part 2. European Journal of Contemporary Education, 8(1), 215-221. http://doi.org/10.13187/ejced.2019.1.215

Magsumov, T.A. (2019b). Gender Re(e)volution of commercial schools in Russia in the early XX century. Woman in Russian Society, 1, 133-144. http://doi. org/10.21064/WinRS.2019.1.12

Masood, O., Tvaronavičiené, M., \& Javaria, K. (2019). Impact of oil prices on stock return: evidence from G7 countries. Insights into Regional Development, 1(2), 129-137. https://doi.org/10.9770/ird.2019.1.2(4) 
Mullins, R. (2019). Using Dewey's Conception of Democracy to Problematize the Notion of Disability in Public Education. Journal of Culture and Values in Education, 2(1), 1-17. Retrieved from http://cultureandvalues.org/index.php/JCV/article/view/24

Nagimzhanova, K. M., Baimanova, L., Magavin, S. S., Adzhibaeva, B. Z., \& Betkenova, M. S. (2019). Basis of psychological and professional personality development of future educational psychologists. Periodico Tche Quimica, 16(33), 351-368.

Nedelkin, A. A. (2018). Russian Universities Under the Conditions of Digital Transformation. Scientific and analytical journal Science and Practice of Plekhanov University, 1(29), 73-77.

Nelson, R. (1993). National Innovation Systems: A Comparative Analysis, New York: Oxford University Press.

North, D. C. (1997). Institutions, Institutional Change and Economic Performance. Moscow: Beginnings. 180 p.

Pavlyshyn, L., Voronkova, O., Yakutina, M., \& Tesleva, E. (2019). Ethical problems concerning dialectic interaction of culture and civilization. Journal of Social Studies Education Research, 10(3), 236-248.

Polozikhina, M.A. (2019). Regulation of the process of digitization of the economy: the European and Russian experience. Russia and the modern world, 4, 64-81.

Polyakova, A. G., Loginov, M. P., Serebrennikova, A. I., \& Thalassinos, E. I. (2019). Design of a socio-economic processes monitoring system based on network analysis and big data. International Journal of Economics and Business Administration, 7(1), $130-139$.

Program "Digital Economy of the Russian Federation" (2017). Approved by order of the Government of the Russian Federation of July 28, 2017 No. 1632-r (2017, July 28).

Rosa, A. T. R., Pustokhina, I. V., Lydia, E. L., Shankar, K., \& Huda, M. (2019). Concept of electronic document management system (EDMS) as an efficient tool for storing document. Journal of Critical Reviews, 6(5), 85-90. http://doi. org/10.22159/jcr.06.05.14

Saenko, N., Voronkova, O., Zatsarinnaya, E., \& Mikhailova, M. (2020). Philosophical and cultural foundations of the concept of "nihitogenes is". Journal of Social Studies Education Research, 11(1), 88-103.

Schumpeter, J.A. (1982). The theory of economic development (a study of entrepreneurial profit, capital, credit, interest and the business cycle). Moscow: Progress.

Selomo, M. R., \& Govender, K. K. (2016). Procurement and Supply Chain Management in Government Institutions: A Case Study of Select Departments in the Limpopo Province, South Africa.

Singareddy, R. R. R., Ranjan, P., Balamurugan, A., \& Shabana, C. (2019). Financial inclusion remodeling: Including the excluded masses. Space and Culture, India, 6(5), 178-188. http://doi.org/10.20896/SACI.V6I5.375

Soldatova G.U., Nestik T.A., Rasskazova E.I., Zotova E.Yu. (2013). Digital competence of adolescents and parents. The results of an allRussian study. M.: Internet Development Fund, 144 p.

Soleimani, M., \& Esfahani, M. K. (2018). The impact of network of social relationships effective in drug addiction and crime in connection with the it. Journal of Social Sciences and Humanities Research, 6(04), 1-5.

Sousa, J. A., Machado, I. D. C. P., \& Barros, F. D. A. A. (2019). Real interest of federal and state institutions in relation to chemistry education with citizenship training. [Real interesse de instituições federal e estadual em relacionar o ensino de química com a formação para cidadania] Periodico Tche Quimica, 16(32), 862-869.

Sturm, E., \& Quaynor, L. (2020). A Window, Mirror, and Wall: How Educators Use Twitter for Professional Learning. Research in Social Sciences and Technology, 5(1), 22-44. Retrieved from https://ressat.org/index.php/ressat/article/view/439

Sycheva, I., Voronkova, O., Vorozheykina, T., Yusupova, G., Semenova, A., \& Ilyin, A. (2019). The main directions of improving the environmental and economic efficiency of regional production. Journal of Environmental Management and Tourism, 10(3), 631-639. http://doi.org/10.14505/jemt.v10.3(35). 17

Tikhonov, A. I., Sazonov, A. A., \& Novikov, S. V. (2019). Digital aviation industry in Russia. Russian Engineering Research, 39(4), 349353. http://doi.org/10.3103/S1068798X19040178

TOP 10 countries with the most developed digital economy (2017). Web-payment.ru (2017, July 12). Retrieved December 03, 2019, from http://web-payment.ru/artic le/250/top-10-cifrovaya-/

Tvaronavičienè M. (2018). Towards internationally tuned approach towards critical infrastructure protection. Journal of Security and Sustainability Issues, 8(2), 143-150. https://doi.org/10.9770/jssi.2018.8.2(2)

Vasetskaya, N.O. (2018). Features of the university management process in the digital economy. Scientific works of the North-West Institute of Management, RANEPA, 9 (4 (36)), 52-60. 
ENTREPRENEURSHIP AND SUSTAINABILITY ISSUES

ISSN 2345-0282 (online) http://jssidoi.org/jesi/

2020 Volume 7 Number 4 (June)

http://doi.org/10.9770/jesi.2020.7.4(39)

Villalobos, J. V. (2018). Politics as a requirement. On the concept of Human Rights and the right to an autobiography as an ethical category. Opción, 34(85-2), 9-19.

$\mathrm{Vu}, \mathrm{T}$. (2019). Theoretical Constructs and Practical Strategies for Intercultural Communication. Journal of Curriculum Studies Research, 1(1), 43-53. Retrieved from https://curriculumstudies.org/index.php/CS/article/view/3

Vural, H. (2019). The Relationship of Personality Traits with English Speaking Anxiety. Research in Educational Policy and Management, 1(1), 55-74. Retrieved from https://repamjournal.org/index.php/REPAM/article/view/9

Yagolkovsky, S. R. (2011). Psychology of innovation: approaches, methods, processes. Moscow: Higher School of Economics.

Yankovskaya, V. V., Ekimova, K. V., Kovalenko, K. E., Novikova, Y. A., Kemkhashvili, T. A., \& Grigorieva, O. G. (2019). Some problems arising in ensuring the right to information of employees. Journal of Legal, Ethical and Regulatory Issues, 22(4)

Yemelyanov, V., Yemelyanova, N., \& Nedelkin, A. (2018). Diagnostic system to determine lining condition. Paper presented at the MATEC Web of Conferences, 172 https://doi:10.1051/matecconf/201817204001

Yli-Viitala, P., Arrasvuori, J., Silveston-Keith, R., Kuusisto, J., \& Kantola, J. (2019). Digitalisation as a driver of industrial renewalperception and qualitative evidence from the USA. Theoretical Issues in Ergonomics Science, http://doi.org/10.1080/1463922X.2019.1621404

Zeibote, Z., Volkova, T., \& Todorov, K. (2019). The impact of globalization on regional development and competitiveness: cases of selected regions. Insights into Regional Development 1(1): 33-47. https://doi.org/10.9770/ird.2019.1.1(3)

Zhao, H., Zhao, Q. H., \& Ślusarczyk, B. (2019). Sustainability and digitalization of corporate management based on augmented/virtual reality tools usage: China and other world IT companies' experience. Sustainability (Switzerland), 11(17) http://doi.org/10.3390/su11174717

Ziyadin, S., Ermekbaeva, B., Supugaliyeva, G., \& Doszhan, R. (2018). Transformation of basic indicators of socio-economic processes in the digital economy. Paper presented at the Proceedings of the 31st International Business Information Management Association Conference, IBIMA 2018: Innovation Management and Education Excellence through Vision 2020, 2009-2017.

Vladimir Lvovich VASILEV, PhD, Candidate of Economic Sciences, Associate Professor of Economics and Management Department, Economics and Management Faculty, Elabuga Institute of Kazan Federal University. 423604, 89, Kazanskaya Street, Elabuga, Republic of Tatarstan, Russian Federation. The author has experience in organizing production in engineering companies: he represented a company producing mini-planes at the St. Petersburg Venture Fair. Currently, the author is also engaged in improving the efficiency of modern industries and introducing lean manufacturing. Research interests: innovation, digitalization, digital technology, digital education.

ORCID ID: orcid.org/0000-0003-2779-8342

Almaz Rafisovich GAPSALAMOV, PhD, Candidate of Economic Sciences, Associate Professor, Head of the Economics and Management Department, Economics and Management Faculty, Elabuga Institute of Kazan Federal University. 423604, 89, Kazanskaya Street, Elabuga, Republic of Tatarstan, Russian Federation. The author specializes in the study of digitalization of educational processes in Russia and the world. Currently, the author is studying the impact of digitalization on national education systems. Research interests: management, digitalization, digital technology, digital education, protectionism.

ORCID ID: orcid.org/0000-0002-8045-623X

Elvir Munirovich AKHMETSHIN, Senior Lecturer of Economics and Management Department, Elabuga Institute of Kazan Federal University. 423604, 89, Kazanskaya Street, Elabuga, Republic of Tatarstan, Russian Federation. Author specializes in the study of the digital transformation of educational organizations. Currently engaged in teaching economics and management disciplines at the Faculty of Economics and Management EI KFU. Research interests: digital transformation of a university, digital educational platform, digitalization of educational services.

ORCID ID: orcid.org/0000-0002-2576-503X 
ENTREPRENEURSHIP AND SUSTAINABILITY ISSUES

ISSN 2345-0282 (online) http://jssidoi.org/jesi/

2020 Volume 7 Number 4 (June)

http://doi.org/10.9770/jesi.2020.7.4(39)

Tatyana Nikolaevna BOCHKAREVA, PhD, Candidate of Pedagogical Sciences, Associate Professor of Pedagogy Department, Psychology and Pedagogy Faculty, Elabuga Institute of Kazan Federal University. 423604, 89, Kazanskaya Street, Elabuga, Republic of Tatarstan, Russian Federation. The author has experience in the preparation and organization of a master's program in the direction of training teacher education, profile management of an educational organization. Currently, the author is engaged in teaching special disciplines for analysis and increasing the effectiveness of the educational process at the Faculty of Economics, Faculty of Psychology and Psychology of EI KFU and research in the field of innovative technologies in education, the use of active pedagogical technologies in education. Research interests: modern education - digital technologies in teaching, information competence of the teacher in the field of IT application in the educational process.

ORCID ID: orcid.org/0000-0002-1232-1886

Alexei Valerievich YUMASHEV, Doctor of Medicine, professor, Department of Prosthetic Dentistry, Sechenov First Moscow State Medical University.

Research interests: Business, Management and Accounting Economics, Econometrics and Finance, Social Sciences, Chemistry Dentistry, Medicine, Computer Science, Pharmacology, Toxicology and Pharmaceutics, Environmental Science, Chemical Engineering.

ORCID ID: orcid.org/0000-0002-5184-0195

Tatyana Ivanovna ANISIMOVA, PhD, Candidate of Pedagogical Sciences, Associate Professor and Head of the Mathematics and Applied Computer Science Department, Mathematics and Natural Sciences Faculty, Elabuga Institute of Kazan Federal University. 423604, 89, Kazanskaya Street, Elabuga, Republic of Tatarstan, Russian Federation. The author specializes in the study of digitalization of educational activities of the University. Research interests: digitalization, digital technologies, digitalization of research activities, distance learning technologies.

ORCID ID: orcid.org/0000-0002-3451-2587

Register for an ORCID ID:

https://orcid.org/re gister

Copyright (C) 2020 by author(s) and VsI Entrepreneurship and Sustainability Center

This work is licensed under the Creative Commons Attribution International License (CC BY).

http://creativecommons.org/licenses/by/4.0/

(c) (†) Open Access 